\title{
Erdogans Tyrkiet - et bud på diagnoser
}

Af Lasse Ellegaard

På indersiden af offentlige tyrkiske toiletdøre ses ofte en seddel med teksten: Buldugun Gibi Birak -'efterlad dette sted som De forefandt det'. Formaningen til toilethygiejne er en tilbagevende vits, når den yngre sekulære storbygeneration mødes til fredagsbar i den populære Midpoint café i det centrale Istanbul.

Vitsen er selvsagt møntet på præsident Recep Tayyip Erdogan, skønt ingen ved bordene med $ø l$, espresso, te og ostekage nævner hans navn. Dels ved de ikke, hvem der lytter med ved nabobordet, dels er det unødvendigt - der er kun én politiker, der kan klandres for, at deres situation nærmer sig den morgen i februar 2001, da deres forældre vågnede op til en lira-kurs, der i løbet af natten havde tabt en tredjedel over for dollaren.

Og den politiker er præsidenten, der i juni 2018 erobrede staten med sin sejr ved præsidentvalget og med intervention i centralbankens rente- politik, udnævnelse af sin svigersøn til finansminister og sit offentlige kriseskænderi med Washington sendte lira'en i frit fald, så den endte med et tab på 40 pct. af dollarkursen. En nedtur, der kreerede toiletdør-vitsen.

Dengang i 2001 faldt lira'en på en nat med en tredjedel, og pengene fossede ud af den tyrkiske økonomi, da investorer i panik solgte deres aktier og hævede deres indeståender. I forvejen var Tyrkiet ramt af en tårnhøj inflation på næsten 80 pct., en ungdomsarbejdsløshed på 20-25 pct. og en rente, der nærmede sig 1000 pct. En IMF-lånepakke på syv mia. dollar - det var mange penge i 2001 - var netop bakset på plads med de sociale skadevirkninger, det medførte.

Årsagen var både dramatisk og patetisk: Præsident Ahmet Necdet Sezer, en tidligere dommer, havde på et rutinemøde i Det Nationale Sikkerhedsråd smidt et eksemplar af den tyrkiske forfatning på bordet foran Bülent Ecevit, leder af den daværende koaliti- 
5

I en bizar sammenblanding af politisk ustabilitet, hjerneflugt, forfejlet rentepolitik, politisk gidseltagning og sejlende udenrigspolitik gennemlevede tyrkisk økonomi den værste krise siden krisen i 2001.

onsregering, med ordene: "Du sidder i mudder". Hvormed han mente, at Ecevit-regeringens indsats i bekæmpelsen af korruption var så sløj, at han selv overtog tilsynet med de tyrkiske banker, der blev systematisk plyndret af de politiske partier.

Socialdemokraten Ecevit, en af den tids få politikere med ry for rene hænder, men også med et stolt temperament, stormede ud fra mødet og gik på direkte tv samme aften med en erklæring om, at 'vi har en alvorlig krise'. Mere skulle der ikke til. Da tyrkerne vågnede næste morgen, var Tyrkiet en fattiggård.

I efteråret 2018 var situationen ikke tilsvarende - og dog. I en bizar sammenblanding af politisk ustabilitet, hjerneflugt, forfejlet rentepolitik, politisk gidseltagning og sejlende udenrigspolitik gennemlevede tyrkisk $\varnothing$ konomi den værste krise siden krisen i 2001 - som ironisk nok var krisen, der blev direkte årsag til, at Erdogans parti, AKP (Adalet ve Kalkinma Partisi - Partiet for Retfærdighed og Udvikling) vandt parlamentsvalget $\mathrm{i}$ november $2002 \mathrm{og}$ banede vejen for den da 48-årige ambitiøse opkomling fra Istanbuls rustikke Kasimpasha-nabolag som sit lands længst siddende politiske leder.

\section{Vælgernes mand}

I Vesten dæmoniseres Erdogan som islamistisk ulv i demokratiske fåreklæ- der, der via manipulation af vælgerne og notorisk magtmisbrug har tiltaget sig diktatorisk magt. Hans konstatering i perioden som Istanbuls overborgmester i 1990'erne af, at “demokrati er som en sporvogn - du kan stå af, når du når til dit stoppested", citeres igen og igen som bevis for en nedgroet totalitær tendens.

Sådan ser hans vælgere ham ikke. De ser en leder, der er i øjenhøjde med deres virkelighed, som har gennemført hidtil usete sociale og økonomiske reformer med et fungerende sundhedsvæsen, en effektiv infrastruktur - det asfalterede vejnet og antallet af lufthavne er fordoblet i hans periode og som er garant for billig og pålidelig energiforsyning. I det tidlige forår lagde han grundstenen til Tyrkiets første atomkraftværk, der opføres med hjælp fra hans nye ven, Vladimir Putin.

Tyrkiet har på 15 år gennemført et økonomisk vækstmirakel, der har skabt en selvbevidst anatolsk middelklasse med et forbrug, som blev afspejlet i gigantiske butikscentre, og som satte dem i stand til at bytte deres hjemmeproducerede skrumplende Lada-kopier ud med europæiske og japanske biler med servostyring og airbags.

$\mathrm{Nu}$ er det første selvstændige tyrkiske bilmærke lige om hjørnet, hvilket vil stimulere den nationale selvfølelse. Erdogan og hans parti, AKP, skabte på få år to samfundsspor, som ikke var der før: En islamisk modernitet med en betydelig intellektuel basis i 
Erdogans AKP-regering blev genvalgt ni gange ved seks parlamentsvalg og tre lokalvalg - plus rækken af folkeafstemninger om strukturelle reformer, der konsoliderede partilederens magt. af ytrings- og pressefriheden, vilkårlige arrestationer af oppositionelle stemmer, øget selvcensur og censur i tv, aviser og sociale medier, overdreven voldsanvendelse ved nedkæmpelse af protester og - særlig signifikant - en tilbagevenden til 1990'ernes borgerkrig i de kurdiske provinser.

Det har heller ikke påvirket vælgerne, at de siden 2013 har været fuldt informeret om hidtil uset mega-korruption i regering og administration, der rækker helt ind i Erdogans nære familie.

Retssikkerhed har aldrig været en tyrkisk dyd, men er i AKP's periode yderligere underløbet - først i alliancen med den islamiske kult, der ledes af den i USA eksilerede prædikant, Fethullah Gülen; dernæst i et forbitret opgør med kulten, der medførte to års undtagelsestilstand, dekret-lovgivning og inappellabel domspraksis.

Alligevel bliver Erdogan ved med at vinde valgene. stematiske indskrænkninger af demokratiske rettigheder med begrænsning

Gülen-netværket er ubetinget provestligt og tillige økumenisk med en positiv holdning til Israel og et budskab om dialog mellem trosretningerne - i samme anledning har Fethullah Gülen været $\mathrm{i}$ audiens hos paven. Netværket driver en vidt forgrenet international uddannelsesorganisation med skoler og læreanstalter i en lang række lande, der indtil bruddet med Erdogan også fungerede som uofficielle nationalistisk-tyrkiske ambassader og spionreder. Der er indicier for, at Gülen-skolerne i de centralasiatiske republikker, der fik selvstændighed efter Sovjetunionen, var dække for CIA-agenters arbejde i regionen. I hvert fald har Gülen en loyal ven i tidligere CIA-stationschef i Kabul, Graham Fuller, der i 2006 sagde god for Gülen i et brev til FBI, der havde overvejelser om at inddrage prædikantens USA-opholdstilladelse. 


\section{Det tyrkiske forår}

Ret beset varede AKP's 'tyrkiske forår' fem år - fra valgsejren i 2002 til udenrigsminister Abdullah Gül tiltrådte præsidentembedet i 2007. Og der var ingen ende på sympatien - heller ikke internationalt.

Vestens politikere og medier roste Erdogan som den længe ventede muslimske humanist og demokrat, der kunne bygge bro til islam efter 11. september - AKP blev stiftet som et 'konservativt demokratisk' parti, tre uger før flyene torpederede Twin Towers i New York. Det forstyrrede ikke den vestlige ønsketænkning, at AKP-politikernes pludselige hamskifte fra radikal islamisme til en slags parallel til Tysklands Kristelige Demokraterx var gået lige lovlig hurtigt.

Men også det hidtil islam-skeptiske segment blandt de tyrkiske vælgere købte konceptet ubeset - venstreorienterede og liberale sekulære stemte på AKP, hvilket betød, at stemmeandelen fra tiden med de erklærede islamiske partier med 15-20 pct. af stemmerne steg til mere end 34 pct. i 2002, til 47 pct. i 2007 og til knap 50 pct. i 2011.

I de første fem år oplevede tyrkerne en periode, hvor befolkningen - hele befolkningen inklusive kurdere og kristne - for første gang kunne ånde, tænke og tale frit. Der var kommet mere ro på i de kurdiske områder, hvor PKK frem til 2004 opretholdt en ensidigt erklæret våbenhvile, tortur på politistationerne var i det store og hele ophørt, og demokratiske reformer blev iværksat som optakt til tyrkisk EU-medlemskab.
Den nationale selvfølelse fik massage, da Tyrkiet for første gang vandt Eurovisions internationale melodi grandprix i 2003, og endnu et pift opad med anerkendelsen som EU-ansøger fra 2005. En valutareform øgede tilliden til lira'en og bragte inflationen under kontrol, den maleriske storby-slum blev erstattet af højhusbyggeri med badeværelser, og den første civile generalsekretær for det nationale sikkerhedsråd begyndte at invitere til pressemøder.

\section{Vejen til totalitarisme}

Det blev et afgørende vendepunkt, at udenrigsminister Abdullah Gül efter parlamentarisk besvær blev valgt til præsident i 2007. Indtil da havde den stædigt sekulære præsident Ahmet Necdet Sezer begrænset AKP's massive udskiftning af administrationens topembedsmænd.

Da han gik af, havde han blokeret 65 lovforslag ved at sende dem tilbage til parlamentet med den begrundelse, at de var på kanten af det forfatningsstridige. Med Abdullah Güls indflytning i Cankaya-residensen var den bremseklods ryddet af vejen - AKP havde nu kontrollen med både parlament og præsidentembede, altså staten.

En anden virkning var, at Güls funktion som korrektiv til Erdogans excesser ophørte. Ikke længere medlem af partiet svandt Güls indflydelse i parti og parlamentsgruppe, hvor han som fremtrædende medstifter og udenrigsminister havde haft betydelig indflydelse. Som britisk uddannet $\varnothing$ konom og med erfaring fra den 
islamiske udviklingsbank i Jeddah, Saudi-Arabien, var hans intellektuelle kredit og religiøse status på et niveau, der satte ham i stand til som den eneste at imødegå og korrigere den populære partiformands underliggende totalitære tendenser.

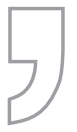

\section{Under den affable facade var også Gül islamist og først} derefter demokrat. I hvert fald skrev han under, når Gülen-netværket blev belønnet med dommerembeder og chefstillinger for at gøre det beskidte arbejde med at udrense kemalismens statsbærende elite

I hvor høj grad, Gül forsøgte at præge politikken, vil næppe blive opklaret - dogmatisk loyalitet sik- rede udadtil partiet mod uenighed, der kunne betyde dets endeligt - i de første år i regering havde AKP hovedparten af den toneangivende presse imod sig. At der var politiske uenigheder mellem de to ledere - nogle af dem er skildret $i$ en autoriseret biografi om Gül - er evident, men som præsident blandede Gül sig ikke i den interne partipolitik. Og man kan tvivle på, om Gül ville have bremset det mest skæbnesvangre fejltrin, som var alliancen med Fethullah Gülen og

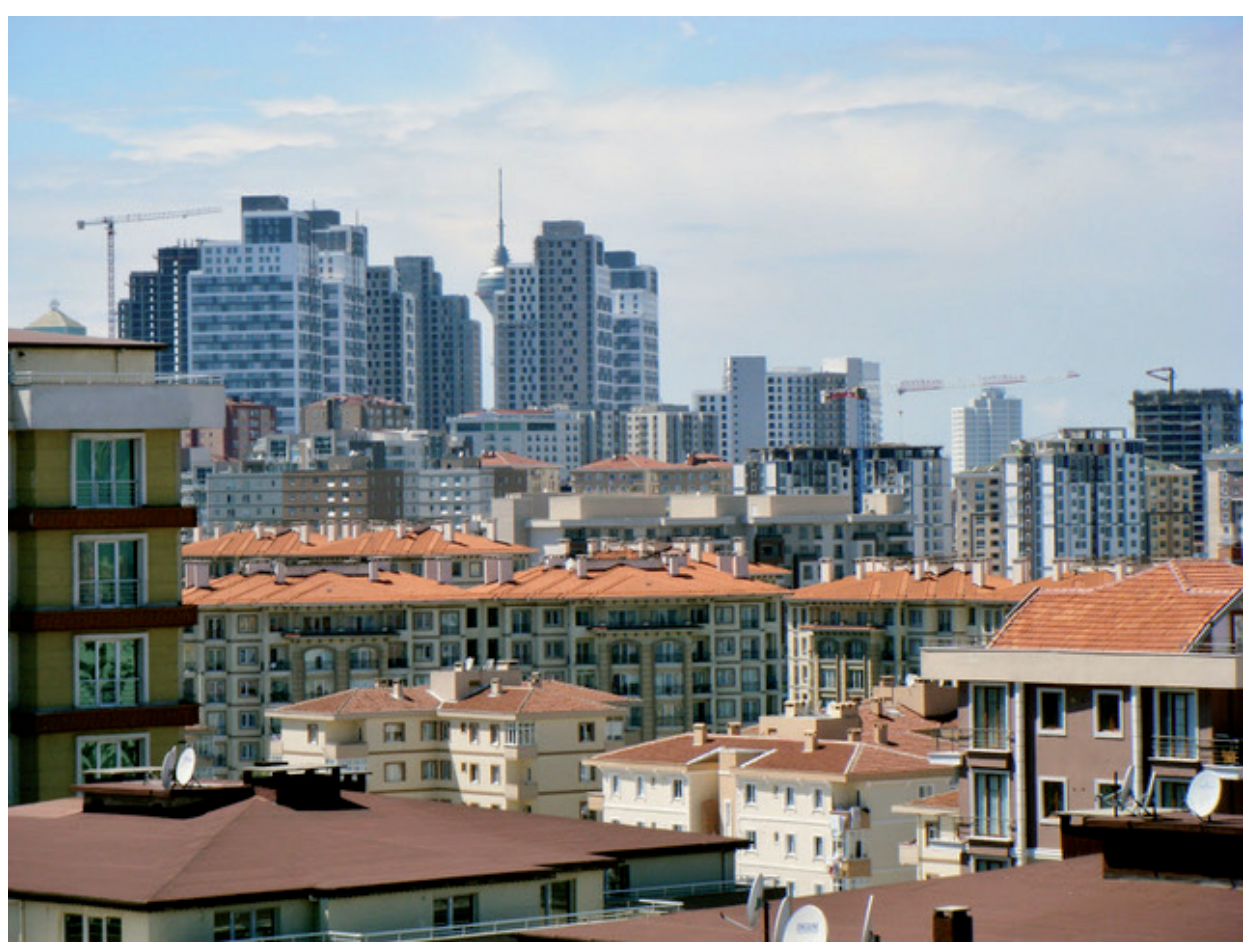

FOTO: buzkozan via Wikimedia Commons 
iværksættelsen af den såkaldte Ergenekon-sag, der tillige med en lignende senere sag Balyoz (Forhammer) - varslede, hvad der var på vej.

Under den affable facade var også Gül islamist og først derefter demokrat. I hvert fald skrev han under, når Gülen-netværket blev belønnet med dommerembeder og chefstillinger for at gøre det beskidte arbejde med at udrense kemalismens statsbærende elite, der fulgte nationsbygger Mustafa Kemal Atatürks doktriner.

De to sager, Ergenekon og Balyoz, blev præsenteret som sinistre sekulære konspirationer, der måske/måske ikke pønsede på at vælte den demokratisk valgte regering.

Nogle har sikkert ønsket at vælte regeringen, men hvor mange, der gjorde noget ved det, er umuligt at sige noget sikkert om. Flere hundrede pensionerede og aktive officerer plus en hel del akademikere og journalister blev fængslet på sigtelser, der senere viste sig at være fabrikation. Sagerne blev indledt umiddelbart efter, at den tyrkiske chefanklager - Abdurraman Yalcinkaya hed han - havde anmeldt AKP og 70 af partiets fremtrædende politikere til forfatningsdomstolen for at være 'fokuspunkter for islamisk virksomhed' med krav om forbud og lukning.

\section{Mislykket militærkup}

Partiet overlevede med nød og næppe, men katten var ude af sækken, og de næste 10 år formede sig som en civil borgerkrigstilstand - i to faser. Den
Bag Gülen-netværkets moderate image som moderne islamister med inter-religiøs dialog på programmet var kernen i netværket benhård nationalisme og dermed de facto allieret med kemalismens nationalistiske og sekulære opposition.

første var Erdogans alliance med Fethullah Gülens islamiske netværk, der gennemførte den politiske udrensning af kemalismens gamle sekulære elite i administrationen, militæret, retssystemet og til en vis grad i medierne.

Da den krig var vundet i 2010 med en kombination af politiske reformer og beskidte tricks, vendte Erdogan sig mod Gülen-netværket, der gjorde krav på medindflydelse, men uden at tage politisk ansvar - netværket var ikke organiseret, men infiltrerede de eksisterende politiske parter. Modsætningerne udviklede sig i løbet af 2011-12 til en forbitret magtkamp om kontrol med staten, der kulminerede med det mislykkede militærkup i juli 2016, som endegyldigt eliminerede Gülens netværk i Tyrkiet.

I den periode brugte Erdogan betydelig energi på at afværge Gülens angreb og konsolidere kontrol med parti og stat. Eftersom den tyrkiske forfatning foreskrev, at partiernes ledere er suveræne ved udpegning af kandidater til politiske tillidsposter - eller som den bistre politolog Dogu Ergi har sagt det: partiformændene er sultaner - havde Erdogan frit løb til at gennemføre sin egen udrensning i parti og parlamentsgruppe.

Med Abdullah Gül ude af billedet blev andre fremtrædende reformister som parlamentsformanden Bülent 
Arinc og politologen Abdullahtif Sener gradvist marginaliseret, og AKP ændret fra et bredt parti til unison klakør for Erdogan. Frem til 2007 var parlamentsgruppen sammensat af traditionelle islamister og frafaldne fra centrum-højrepartiernes politiske og moralske deroute og bestod reelt af fire fraktioner, en islamisk, en nationalistisk, en konservativ og en liberal - og såmænd også en Gülen-fløj.

Som en anonym AKP-deputeret formulerede det: "Efter 2007 gik partiet fra at være et vi til at blive et jeg".

\section{Det kurdiske spor}

Fup-retssagerne mod den kemalistiske elite, marginaliseringen af intern opposition i partiet og senere udrensningen af tidligere allierede gülenister, som AKP havde hjulpet til centrale positioner i anklagemyndighed og dommerstand, skaffede Erdogan albuerum til hans store forkromede plan om at være lederen, der løste det kurdiske problem.

Og her skal man huske, at bag Gülen-netværkets moderate image som moderne islamister med inter-religiøs dialog på programmet, var kernen i netværket benhård nationalisme og dermed de facto allieret med kemalismens nationalistiske og sekulære opposition.

Såvel CHP (Cumhuriyet Halk Partisi - Republikansk Folkeparti (grundlagt af Kemal Atatyrk)) som - og især det ultra-nationalistiske MHP (Milli Harekat Partisi - National Aktions Parti), var indædte modstandere af Erdogans forsøg på at afslutte den blodige og kostbare konflikt med de kurdiske separatister i PKK, der siden 1984 havde kostet 40.000 dræbte og tre mio. interne flygtninge og medført et anslået drop i BNP på 14-15 pct.

Opmuntret af den fængslede PKK-leder, Abdullah Öcalan, der fra cellen på fængselsøen Imrali i Marmarahavet havde signaleret, at PKK var klar til at fravige kravet om en selvstændig kurdisk stat og gå efter kulturel og politisk autonomi inden for rammerne af den tyrkiske stat, indledte Erdogan de første sonderinger om en fredsløsning allerede i 2004 og med konkret substans fra 2009. Og i maj 2013 indledte han den såkaldte 'løsnings-proces', hvor regeringen for første gang forhandlede i åbenhed med PKK.

Efter at have forsøgt forskellige bespænd i 2012 lækkede gülenister i bagmandspolitiet i december 2013 en stribe aflytninger, der dokumenterede omfattende korruption med milliard-kontrakter til Erdogans forretningsforbindelser mod passende returkommission - en skandale, der rakte helt ind i Erdogans nære familie.

I januar 2014 afslørede gülenister i politi og anklagemyndighed ulovlige transporter af våben til fundamentalistiske jihad-militser i Syrien - muligvis med al Qaeda-tilknytning. Hensigten med disse læk var åbenlys for enhver: At skade og helst vælte AKP-regeringen. Men lige lidt hjalp det - vælgerne blev ved med at støtte Erdogan.

Hans svar på Gülen-angrebene var dels lovgivning, der strammede regeringens kontrol med politi og retsvæsen (og samtidig bidrog substantielt 
til hans egen autokratiske magt), dels fyringer og forflytninger i sikkerhedssystemerne og administrationen. I den proces kom Erdogan samtidig af med potentielle politiske rivaler og tidligere partnere, der i det stille modarbejdede Erdogans ambition om at ændre forfatningen til præsidentielt system.

Juristen Bülent Arinc, der faktisk var den, der oprindeligt stod i spidsen for dannelsen af AKP, er i dag helt ude af politik, mistænkt for relationer til Fethullah Gülen. Også den noget yngre finansminister og senere udenrigsminister, Ali Babacan, der blev kaldt Tyrkiets økonomiske troldmand, er smidt ud af partiets ledende organer, mistænkt for at have været for tæt på Gülen.

Ahmet Davutoglu, den akademiske premierminister, der tiltrådte i 2014, da Erdogan blev præsident, blev summarisk fyret i maj 2016, kun uger efter at han i Bruxelles havde bakset flygtningeaftalen med EU på plads. Hans brøde var at tage æren for flygtningeaftalen og arbejde for dens implementering på EU's præmisser, hvilket krævede en lempelse af terrorlovgivningen.

Et håb om, at Abdullah Gül - den anden titan i AKP - ville udfordre Erdogan ved at opstille til præsidentvalget i 2018, blev skrinlagt. Kort før fristen for kandidatur til præsidentvalget udløb, landede en helikopter på Güls græsplæne og ud steg generalstabschefen og chefen for efterretningstjenesten. Da de fløj væk nogle timer senere, meddelte Gül, at han ikke var præsidentkandidat.
Og Erdogan selv? Han var optaget af forfatningsændringen, der ville sikre vedtagelse af et præsidentielt system. Da det i sommeren 2015 stod klart, at det legitime kurdiske politiske parti, HDP, ikke ville stemme for det ændringsforslag, der skulle sikre, at det præsidentielle system blev afprøvet ved en folkeafstemning, opgav han den kurdiske forhandlingsløsning, han selv havde igangsat, og undsagde kategorisk det forhandlingsresultat, som hans egen regering og de kurdiske politikere var nået frem til, og som var blevet offentliggjort på nationalt tv.

Men allerede medens Erdogans regering forhandlede med PKK om en køreplan for den videre fredsproces, var der problemer. En aftalt tilbagetrækning af PKK-enheder fra tyrkisk territorium blev ikke fuldt implementeret, idet Erdogan forhalede et løfte om at skabe en lovgivningsmæssig ramme for tilbagetrækning og senere afvæbning af PKK's styrker. Og PKK indstillede tilbagetrækningen, da det viste sig, at det tyrkiske militær udbyggede beredskabet i de kurdiske provinser.

Et IS-selvmordsangreb i den kurdiske by Suruc i juli 2015 betød, at den i forvejen skrøbelige våbenhvile mellem Tyrkiet og PKK kollapsede, og borgerkrigen blussede op igen med overraskende voldsomhed. Som om begge parter kun havde ventet på at gå løs på hinanden.

I stedet allierede Erdogan sig med sin tidligere ærkefjende, MHP-nationalisterne, der leverede de sidste nødvendige mandater i Nationalforsamlingen, så forslaget til forfatningsændringerne 
2)

Relationerne til EU har i realiteten været anstrengte siden 2006 , da Ankara afviste at lade græskcypriotiske skibe og fly anløbe tyrkiske destinationer.

kunne sendes til folkeafstemning. En enestående mulighed var tabt på gulvet, men det var ikke kun Erdogans skyld de kurdiske politikeres og PKK's arrogance kombineret med oppositionens skrækkampagne gjorde det umuligt for ham at nå en løsning.

\section{Post-Gülen}

Om sit tætte samarbejde med Gülen havde han kun den kommentar, at han 'var blevet snydt' efter at have givet Gülen 'alt det, denne havde bedt ham om'! I hans optik var der tale om en politisk eksistenskamp efter kupforsøget, der efter alle indicier at $\mathrm{d} ø \mathrm{~m}$ me blev iværksat af Gülen-tilhængere i officerskorpset.

Indtil videre er 150.000 fyret eller suspenderet og 77.000 fængslet eller anholdt, sigtet for at tilhøre Gülens 'parallelle stat' eller, som regeringen kalder netværket, 'FETÖ, Fethullah Gülens Terror Organisation’. Bølger af arrestationer i denne den største udrensningsbølge siden militærkuppet i 1980 fortsætter på tredje år. Prisen er en åreladning af ekspertise. En tredjedel af anklager- og dommerstanden er enten fyret eller fængslet og erstattet af nybagte juridiske kandidater.

Men kupforsøget medførte også, at Erdogan med sin alliance med nationalisterne fik sit ønskede flertal for at udskifte den tyrkiske parlamentarisme med et énmandsstyre, der samler den lovgivende, udøvende og dømmende magt i det nye, pompøse præsidentpalads. I den forstand var kupforsøget, som Erdogan spontant udtrykte det, 'en gave fra Gud'.

Kupforsøgets nærmere omstændigheder er belyst i alenlange rapporter, men det betyder ikke, at det er fuldt opklaret - den parlamentariske kommission, der blev nedsat for at afdække dets baggrund og årsager, blev lukket ned på ordre af Erdogan, hvilket betød, at centrale vidner ikke blev afhørt - CHP-medlemmerne af kommissionen fik afvist en mindretalsudtalelse til rapporten, som i stedet blev udgivet separat og næsten ikke omtalt i de tyrkiske medier.

Allerede før kupforsøget, men i særlig grad efter, er Tyrkiets forhold til Vesten og i særlig grad USA smuldret til en politisk væbnet neutralitet. Relationerne til EU har i realiteten været anstrengte siden 2006, da Ankara afviste at lade græsk-cypriotiske skibe og fly anløbe tyrkiske destinationer - en reaktion på den græsk-cypriotiske regerings veto i EU, der sikrede en fortsat opretholdelse af EU-sanktioner mod Den Tyrkiske Republik Nordcypern. Dette veto var et løftebrud, idet Bruxelles havde signaleret, at sanktionerne mod Nordcypern ville blive lempet efter Cyperns EU-medlemskab.

Optagelsesforhandlingerne har været lagt på is i mere end 10 år, og en planlagt opgradering af den toldunion, som Tyrkiet indgik med EU i 1996, blev suspenderet på tysk initiativ i 2017. Det var trods alt for stygt for den ellers tålmodige Angela Merkel, at 
EU's bekymring rakte - og rækker - ikke længere end til den flygtningeaftale, der blev indgået i marts 2016, og som sikrer, at mere end tre millioner syriske flygtninge bliver på den rigtige side af Bosporus.

Erdogan beskyldte hendes regering for at bruge 'nazistiske metoder' i de verbale fejder, der i realiteten afspejlede en tyrkisk skuffelse over manglende opbakning fra EU efter det fejlslagne kupforsøg.

Erdogan og hans rådgivere er overbeviste om, at såvel USA som EU i det stille håbede på, at kupmagerne fik ram på ham. Og det er faktisk tænkeligt, når man ser tilbage på de valne reaktioner, medens kuppet endnu var i udvikling.

I forvejen var Europa bekymret over Erdogans dekonstruktion af tyrkisk demokrati som folkevalgt præsident. Også før kupforsøget fandt overgreb mod ytrings- og pressefriheden sted, folk blev fængslet på mistanker om relationer til PKK, og Gülen-virksomheder blev chikaneret eller beslaglagt. Men EU's bekymring rakte - og rækker - ikke længere end til den flygtningeaftale, der blev indgået i marts 2016, og som sikrer, at mere end tre millioner syriske flygtninge bliver på den rigtige side af Bosporus frem for at bevæge sig nordpå ad det europæiske motorvejsnet.

\section{Erdogans High Noon}

Men mest bekymrende for Erdogan blev hans holmgang med Donald Trump. Under en relativt banal gidselsag - anholdelsen i Izmir af en 50-årig amerikansk præst, Andrew
Brunson, der blev sigtet for spionage - ligger interessemodsætninger, der handler om Ankaras nationale sikkerhedsinteresser, og som går tilbage til Barack Obamas ageren i det syriske borgerkrigsteater - i øvrigt i strid med rådgivning fra hans to udenrigsministre, Hillary Clinton og John Kerry.

Obama havde to interesser i Syrien, der kolliderede med Erdogans - den ene var ambitionen om at afslutte en atomaftale med Iran, den anden var at nedkæmpe Islamisk Stat, IS, i Syrien og Irak.

Atomaftalen indebar, at USA fredede Irans militære og økonomiske bistand til Bashar al-Assads styre i Damaskus - hvilket betød, at Obama trods erklæringer om det modsatte i realiteten fredede Bashar al-Assad. Det stod klart, da USA veg tilbage fra truslen om at bombe Damaskus, hvis det syriske styre anvendte kemiske våben mod oprørerne. I stedet overlod Washington Syrien-kapitlet til Ruslands præsident Putin.

Allerede i efteråret 2011 havde Erdogan - efter adskillige forsøg på at mægle i den syriske konflikt - droppet kontakten til det syriske styre og resolveret, at Bashar al-Assad skulle væltes. Erdogan installerede den syriske opposition i Istanbul, og dens væbnede arm, FSA (Frie Syriske Armé), blev polstret økonomisk og militært. På det tidspunkt stod de første 'rådgivere' fra Irans revolutionsgarde allerede i Syrien. Det var ikke i Obamas interesse, at Bashar-styret faldt, da det ville medføre en krise for atomaftale-projektet. 
Den anden interessemodsætning mellem Ankara og Washington var USA's brug af syrisk-kurdiske styrker som landtropper i krigen mod IS.

Det betød massiv amerikansk støtte til det syrisk-kurdiske parti PYD (Demokratisk Unions Parti) og dets milits YPG (Folkets Beskyttelses Enheder).

Problemet for Tyrkiet var indlysende: PYD er en filial af PKK med Abdullah Öcalan som fælles politisk leder. Alliancen med USA er uforståelig i Ankara - dels er PKK på USA's og EU's terrorliste, dels er USA og Tyrkiet allierede i NATO. Ville tyrkiske styrker kunne være USA-allierede i krigen mod IS?

Amerikanerne var tilsyneladende i tvivl - interessekonflikten blev tydelig for enhver i efteråret og vinteren 201415, da IS belejrede den syrisk-kurdiske by Kobane nær grænsen til Tyrkiet. Tyrkiske tanks stod parkeret på den tyrkiske side med udsigt til Kobane uden at løsne et skud til støtte for kurderne mod kalifatets stormløb, men for at forhindre tyrkiske PKK-krigere $i$ at komme deres syriske fætre til undsætning via det sydlige Tyrkiet.

På et tidspunkt under belejringen erklærede Erdogan ligefrem, at 'Kobane vil falde’. Han måtte dog bøje sig for amerikansk og internationalt pres og tillade, at en nordirakisk pershmega-deling omsider kom Kobane til undsætning, og i januar 2015 blev IS slået tilbage af den kurdiske styrke støttet af amerikanske kampfly.
Senere på året måtte Erdogan modstræbende gå med til at åbne Incerlik-basen i det sydlige Tyrkiet for amerikanske (og danske) kampfly i krigen mod IS, ligesom han lod Tyrkiet indgå i USA's 'koalition af villige', der var mobiliseret mod jihadisternes kalifat.

Men det var ikke i tyrkisk interesse at engagere sig direkte i krigen mod IS; med kalifatet integreret i Tyrkiet IS-kommandanter holdt møder og tog på ferieophold i Mardin, Sanliurfa og Gaziantep - var tyrkisk tilslutning til koalitionen en national sikkerhedsrisiko. Den viste sig da også straks efter med spektakulære terrorangreb i Ankara og Istanbul, der efterlod hundredvis af dræbte.

Når Erdogan alligevel gik med i koalitionen, var det i forventning om, at USA ville droppe eller i det mindste nedtone samarbejdet med YPG-militsen, som set fra Ankara er en større trussel mod Tyrkiets sikkerhed end IS.

PYD-YPG er en organisk del af PKK via den pan-kurdiske organisation KCK (Kurdiske Samfunds Union), der er etableret af PKK. Og da USA trods gentagne opfordringer fra Ankara afslog at droppe alliancen med de syriske kurdere, også efter at IS reelt var nedkæmpet, steg spændingen mellem de to NATO-allierede - og den er stigende, medens dette skrives.

Tyrkiet frygtede, at de amerikanske våben ville sætte PYD i stand til at etablere en sammenlægning af de kurdiske enklaver øst og vest for

Når Erdogan alligevel gik med i koalitionen, var det i forventning om, at USA ville droppe eller i det mindste nedtone samarbejdet med YPG-militsen, som set fra Ankara er en større trussel mod Tyrkiets sikkerhed end IS. 
Eufrat-floden, hvilket ville betyde, at Tyrkiet syd for grænsen havde et kurdisk bælte, der strakte sig fra Middelhavet til Iran.

Så i 2016 og 2017 invaderede tyrkiske styrker det nordlige Syrien - officielt for at bekæmpe IS, reelt for at hindre de kurdiske enklaver - kaldet Rojava - i at forenes øst og vest for Eufrat. Tyrkerne har lige siden forhandlet med amerikanerne om kontrollen over det nordlige Syrien omkring byerne Raqqa og Manbij, som YPG har besat, og trods forhandlinger og aftaler om fælles tyrkisk-amerikansk patruljering, der sikrer, at YPG trækker sig tilbage, er intet sket på landjorden.

Disse modsætninger er forklaringen på den tyrkiske tilnærmelse til Ruslands Vladimir Putin og Irans revolutionsgarde - begge garanter for Bashar al-Assads overlevelse. Men for Tyrkiet og Erdogan er Bashar al-Assad, der har ansvaret for drab på hundredtusinder sunni-muslimer, et mindre problem end en autonom, sammenhængende kurdisk enklave syd for grænsen.

En sådan enklave vil uundgåeligt påvirke tyrkiske kurderes aspirationer og altså styrke PKK.

\section{Fraværet af opposition}

Bortset fra valget i november 2002, hvor han i øvrigt var i karantæne som kandidat, har Erdogan aldrig fået under 40 pct. af stemmerne - ved valget i 2011 fik partiet over 49 pct. Som folkevalgt præsident i 2014 og 2018 har han hver gang rundet de 50 pct.

Generelt er hans valgsejre vundet ved frie valg - manipulationer har været få og bortset fra lokalvalget i
Ankara 2014 uden nævneværdig betydning for det endelige resultat. Han bakkes altså i runde tal op af omtrent halvdelen af befolkningen nemlig den halvdel, der udgør segmentet af 'sorte' tyrkere med 'asiatiske' rødder i Anatolien, ringere uddannet og fattigere end de 'hvide' tyrkere med europæiske rødder på Balkan, der traditionelt udgjorde republikkens militære og administrative elite.

Atatürk fra Makedonien var med sine blå øjne en typisk 'hvid' tyrk, hvorimod Erdogan ikke uden selvfølelse har erklæret sig som 'sort' tyrk og har endda antydet, at hans familie har rødder i laz-stammen, en etnisk minoritet langs Sortehavskysten, oprindeligt fra Georgien men til stede i det nordøstlige hjørne af Tyrkiet med byerne Trabzon og Rize, hvor Erdogan-familien kommer fra.

Trods den tyrkiske forfatnings rigide definition af 'tyrkiskhed' - er en person statsborger, er han eller hun tyrkisk, basta! - er identitet et afgørende parameter. Spørger man en araber om identitet, er svaret en geografisk henvisning: Jeg er fra Nablus, Damaskus, Aleppo, Bagdad, Jerusalem. Stiller man samme spørgsmål til en tyrk, er svaret etnisk-religiøst: jeg er kurder, alevi, armenier, græsk-ortodoks, kaukasier eller sunnit. Antropologer har udregnet, at Tyrkiet har 43 forskellige etniske og religiøse identiteter.

Dette er en medårsag til, at Erdogan har været velsignet med et permanent fravær af alternativer. Den sekulære opposition har ikke på noget tidspunkt vist sig i stand til at producere 
en politisk leder, der når ham til anklerne. Den undtagelse, der i karisma og retorik kunne give Erdogan kamp til stregen, er den næsten 20 år yngre frontfigur i det rød-grønne parti HDP (Halk Demokratik Partisi - Folkets Demokratiske Parti), Selahattin Demirtas. Men som kurder er han uden chance. Fængslet siden november 2016, sigtet for at støtte kurdisk terrorisme, stillede han op som kandidat til præsidentposten i juni 2018 og fik efter en valgkamp fra fængselscellen 8,4 pct. af stemmerne.

Den sekulære oppositionsleder, Kemal Kilicdarogu, formand for CHP (Cumhuriyet Halk Partisi - Republikansk Folkeparti), stillede ikke op til præsidentvalget vel vidende, at han som alevi-muslim aldrig kan slå sunnitten Erdogan. I stedet opstillede CHP den relativt ukendte Muharrem Ince, der med ringe mediedækning over for Erdogans monopol på tv-dækningen faktisk førte en vellykket valgkamp, der resulterede i godt 30 pct., altså lige under en tredjedel af stemmerne. Relateret til CHP's normale valgresultater på omkring 20-25 pct. var Ince en sekulær opmuntring.

\section{Økonomiens nedtur}

At den tyrkiske økonomi i begyndelsen af 2017 viste faretruende tegn på metaltræthed, var ikke uventet blandt fagfolk.

Væksten i 00'erne blev i vidt omfang finansieret med kortfristede lån, både fra egne statsejede banker og fra tyske, spanske og italienske banker - de såkaldte hot money, som gradvist tørrede ud efter det mislykkede kupforsøg i juli 2016 med efterfølgende undtagelsestilstand og politisk ustabilitet.

USA's præsident Donald Trumps dekret fra august 2018 om fordobling af told på tyrkisk stål og aluminium et svar på tilbageholdelsen af den amerikanske præst - øgede lira'ens nedadgående spin med et tab på 40 pct. mod dollaren. Det betød, at inflationen steg til 17-18 pct. med pil opad og blev fulgt af en alt for sen renteforhøjelse fra 18 til 24 pct.

For den typiske tyrkiske pensionist betød det et fald i værdien af den månedlige udbetaling fra 800 til 500 dollar.

Med en samlet udlandsgæld på mere end halvdelen af BNP, et underskud på betalingsbalancen på den forkerte side af 50 mia. dollars, beskæring af de offentlige udgifter kombineret med en betydelig kapital- og hjerneflugt er den tyrkiske $ø$ konomi i alvorlige problemer.

Firkantet sagt har AKP-regeringen lånt over evne for at finansiere en stribe infrastrukturprojekter: veje, broer, tunneller under Bosporus, en ny giga-lufthavn i Istanbul og planer om anlæg af en kanal parallelt med strædet. Antallet af nybyggede moskéer og butikscentre er eksploderet de senere år, og adskillige projekter stoppede på halvvejen.

Ingen af disse projekter giver umiddelbart giver noget afkast til staten, men koster på afdragssiden, da de typisk er belånt i udenlandsk valuta primært dollar og euro.

Strukturelt er den tyrkiske økonomi i princippet sund nok med en fungerende finanssektor, en effektiv indu- 


\section{Tyrkiets geopolitiske placering gør, at Europa ikke kan bryde med Erdogan uden at løbe en sikkerhedsmæssig risiko - både for så vidt angår migration som aspektet om øget russisk indflydelse i det østlige Middelhav.}

stri med producerende virksomheder, et rimeligt velfærdsniveau, en fagligt kompetent og flittig befolkning og et stort hjemmemarked.

Krisen er primært en gælds- og valutakrise, men økonomien har været sjusket forvaltet de sidste fem-seks år som en følge af præsidentens mani med at rejse betonmonumenter for sig selv - kombineret med en udskiftning af den professionelle økonomiske ledelse med amatører.

Efter valget i juni 2018 blev AKP-regeringens sidste ædruelige $ø$ konom, Wall Street-bankmanden Mehmet Simsek, udskiftet som finansminister med Erdogans svigersøn, Berat Albayrak, der kommer fra erhvervslivet.
Den dag, Bayrak blev udnævnt, faldt lira-kursen med 3,8 pct. Pragmatikeren Erdogan har derfor åbnet en ny konto i EU - primært hos den største eksportkunde, Tyskland. Budskabet er, at rimelige relationer genetableres, at EU genåbner opgraderingen af toldunionen, og at Tyrkiet garanterer flygtningeaftalens holdbarhed.

Og Europa har ikke noget valg: Tyrkiets geopolitiske placering gør, at Europa ikke kan bryde med Erdogan uden at løbe en sikkerhedsmæssig risiko - både for så vidt angår migration som aspektet om øget russisk indflydelse i det østlige Middelhav.

Så det skal nok gå. 